\title{
Diet and endoparasites of the lizard Gymnodactylus darwinii (Gekkota, Phyllodactylidae) from an Atlantic Rainforest area in southeastern Brazil
}

\author{
Mauricio Almeida-Gomes ${ }^{1 *}$ \\ Davor Vrcibradic ${ }^{2}$ \\ Thiago Maia-Carneiro ${ }^{1}$ \\ Carlos Frederico D. Rocha ${ }^{1}$
}

\author{
${ }^{1}$ Departamento de Ecologia, Universidade do Estado do Rio de Janeiro \\ Rua São Francisco Xavier, 524, CEP 20550-019, Rio de Janeiro - RJ, Brazil \\ ${ }^{2}$ Departamento de Zoologia, Universidade Federal do Estado do Rio de Janeiro \\ Av. Pasteur, 458, Urca, CEP 22240-290, Rio de Janeiro - RJ, Brazil \\ *Corresponding author \\ almeida.gomes@yahoo.com.br
}

Submetido em 13/07/2011 Aceito para publicação em 24/10/2011

\section{Resumo}

Dieta e endoparasitas do lagarto Gymnodactylus darwinii (Gekkota, Phyllodactylidae) de uma área de Mata Attântica no sudeste do Brasil. Neste estudo disponibilizamos informações sobre dieta e endoparasitismo de indivíduos da espécie Gymnodactylus darwinii em uma área de Mata Atlântica no estado do Rio de Janeiro. Em relação à dieta, ortópteros e isópodes foram as presas mais importantes. Uma espécie de nematódeo (Physaloptera sp.) foi encontrada associada ao estômago de um indivíduo, representando um novo registro de hospedeiro para o gênero. Nossos resultados indicam que G. darwini tem uma dieta similar a outras espécies de lagartos da Mata Atlântica, embora diferente da de outras espécies congêneres habitando ambientes abertos.

Palavras-chave: Hábitos alimentares, Lacertilia, Nematoda, Phyllodactylidae

\section{Abstract}

In this study we provide information on diet and endoparasites of individuals of the species Gymnodactylus darwinii in an Atlantic Rainforest area in the state of Rio de Janeiro, Brazil. Regarding diet, orthopterans and isopods were the most important preys. One nematode species (Physaloptera sp.) was found associated to the stomach of an individual, representing a new host record for this genus. Our results indicate that G. darwinii has a similar diet to other lizard species from the Atlantic Rainforest, although different from that of other congeneric species inhabiting open areas.

Key words: Feeding habits, Lacertilia, Nematoda, Phyllodactylidae 
The genus Gymnodactylus Spix, 1825 (Phyllodactylidae) currently includes five species of geckos, distributed along the Atlantic Rainforest, Cerrado, and Caatinga biomes present in Brazil (PELLEGRINO et al., 2005; UETZ; HALLERMANN, 2011). Lizards of this genus are small-bodied, mostly nocturnal and have terrestrial habits (PELLEGRINO et al., 2005). Gymnodactylus darwinii (Gray, 1845) is endemic to the Atlantic Rainforest biome and occurs from the state of Rio Grande do Norte to the state of São Paulo (FREIRE, 1998; UETZ; HALLERMANN, 2011), inhabiting several types of habitats, such as restingas, rainforests, and forest edges, as well as anthropically disturbed environments (HATANO et al., 2001; TEIXEIRA, 2002; DIAS; ROCHA, 2005; ALMEIDA-GOMES et al., 2008). However, it may represent a species complex (FREIRE, 1998; PELLEGRINO et al., 2005). Currently, introductory ecological information available for this species is restricted to a study on diet and habitat use of a population from a disturbed area in the state of Espírito Santo (TEIXEIRA, 2002) and to a report of communal oviposition in the state of Bahia (CASSIMIRO; RODRIGUES, 2010). Regarding endoparasites, there is currently no information available for $G$. darwinii or for any other species in the genus, except for a report of a trematode infecting $G$. geckoides from an unspecified locality in Brazil (see ÁVILA; SILVA, 2010) and for a record of the nematode Spauligodon oxkutzcabiensis infecting Gymnodactylus amarali (as G. geckoides amarali) in the state of Tocantins (GOLDBERG et al., 2010). In this study we analyze the diet of $G$. darwinii in forest remnants in a fragmented landscape in the state of Rio de Janeiro. Additionally, we provide information regarding endoparasites associated to the gastrointestinal tract of this species.

Herpetological surveys were carried out between July 2007 and March 2010 in the forest of Reserva Ecológica de Guapiaçu (REGUA; 22 24' S, 42 44' W) and in 12 forest fragments at its surroundings, in the municipality of Cachoeiras de Macacu, state of Rio de Janeiro, southeastern Brazil. For lizards sampling, we used pitfall traps with drift fences (CORN, 1994), as well as manual collecting during occasional encounters. Each pitfall trap system consisted of eleven 60-liter buckets buried on the ground and set approximately $10 \mathrm{~m}$ apart from each other, with soft plastic drift fences about $50 \mathrm{~cm}$ high extended between them. A total of 15 pitfall trap systems (165 buckets) were established (12 in fragments and three in the "continuous" forest area of the REGUA) and were surveyed during six days at each of five sampling periods (a total of 30 days), totaling 4,950 buckets-days of sampling effort.

After preservation in 10\% formalin and storage in $70 \%$ alcohol, the collected lizards were measured in their snout-vent length (SVL) and jaw width (JW) with a digital caliper (precision of $0.1 \mathrm{~mm}$ ). Specimens were dissected and their stomach contents were analyzed qualitatively and quantitatively. Prey items found in their stomach were identified under a stereomicroscope to the level of Order. Diet was analyzed in terms of number, volume $\left(\mathrm{mm}^{3}\right)$, and frequency of occurrence of prey items. Prey items were counted and measured in their length and width with a digital caliper (precision of $0.1 \mathrm{~mm}$ ) and their volume was estimated using the formula for an ovoid spheroid [V=4 / 3. $\pi$. (L / 2). (W / 2) $)^{2}$, where " $L$ " is the length and "W" is the width of the food item (DUNHAM, 1983). Besides the stomachs, intestines and lungs were also checked for endoparasites. Lizards collected for this study were deposited at the reptile collection of the Museu Nacional, Rio de Janeiro (MNRJ), Brazil, and the endoparasites found associated with them were deposited at the helminth collection of Instituto de Biociências de Botucatu (CHIBB).

A total of 14 individuals of Gymnodactylus darwinii (MNRJ 20558-72) were collected in five forest fragments during the surveys: 11 males $(78.6 \%)$, two females (14.3\%), and one individual (7.1\%) whose sex could not be determined. One of the females, collected in the dry season (July), had two yolked ovarian follicles. The mean SVL of $G$. darwinii in our sample was 51.2 $\pm 4.9 \mathrm{~mm}$ (range: $40.0-59.1 \mathrm{~mm}, \mathrm{~N}=14$ ). The mean JW was $8.9 \pm 0.9$ (range: $7.5-10.9 \mathrm{~mm}, \mathrm{~N}=14$ ). Four $(28.5 \%)$ individuals had empty stomachs and a total of five types of arthropods were consumed by the other lizards. In numerical terms the lizards fed predominantly on orthopterans (66.6\%), followed by isopods (13.3\%). Volumetrically, blattarians ( $55.4 \%$ of the total ingested) and orthopterans (39\%) were the most important items. 
Orthopterans were also the most frequently consumed prey, being found in $57 \%$ of the stomachs analyzed (Table 1). Two nematodes (larvae of Physaloptera sp.; CHIBB 6516) were found in the stomach of one male (overall prevalence $=7.1 \%$ ).

TABLE 1: Number $(\mathrm{N})$, volume $\left(\mathrm{V}, \mathrm{mm}^{3}\right)$, and frequency of occurrence $(\mathrm{F})$ of each category of prey in the diet of Gymnodactylus darwini from the Atlantic Rainforest in the Reserva Ecológica de Guapiaçu and its surroundings, in southeastern Brazil. Percentage values are in parentheses.

\begin{tabular}{lccc}
\hline \multirow{2}{*}{ Prey category } & \multicolumn{3}{c}{ Gymnodactylus darwinii $(\mathrm{N}=14)$} \\
\cline { 2 - 4 } Insecta & $\mathrm{N}(\%)$ & $\mathrm{V}(\%)$ & $\mathrm{F}(\%)$ \\
Blattaria & $1(6.7)$ & $580.7(55.4)$ & $1(7.1)$ \\
Homoptera & $1(6.7)$ & $26.9(2.6)$ & $1(7.1)$ \\
Microcoryphia & $1(6.7)$ & $21.0(2.0)$ & $1(7.1)$ \\
Orthoptera & $10(66.6)$ & $408.2(39.0)$ & $8(57.1)$ \\
Crustacea & & & \\
Isopoda & $2(13.3)$ & $8.9(0.9)$ & $2(14.2)$ \\
Plant material & - & $1.0(0.09)$ & $2(14.2)$ \\
TOTAL & $15(100)$ & $1,046.7(100)$ & - \\
\hline & & &
\end{tabular}

Our study is the first approach to the ecology of Gymnodactylus darwinii in forested areas in the state of Rio de Janeiro. The results indicate that $G$. darwinii has an exclusively carnivorous diet composed of arthropods, with orthopterans and isopods being its main prey. We found a few plant remains, but due to their low volumetric importance and their aspect (small dry pieces of leaves from leaf-litter) we considered it as result of accidental ingestion during prey capture by the lizards. In another study carried out in an anthropically modified area of Atlantic Rainforest in the state of Espírito Santo, the diet of $G$. darwini was numerically dominated by isopods, dipterans, and spiders, and the most frequently consumed prey were isopods, spiders, and cockroaches (TEIXEIRA, 2002). For the lizard Ecpleopus gaudichaudii (Gymnophtalmidae), isopods and orthopterans were among the most frequently consumed items in a population occurring sympatrically with $G$. darwini at the REGUA (MAIA et al., 2011). Isopods have also been reported as the main prey item in the diet of the similar-sized leaf-litter lizard, Leposoma scincoides (Gymnophtalmidae), in an
Atlantic Rainforest area in the state of Espírito Santo (TEIXEIRA; FONSECA, 2003). These results indicate that orthopterans and isopods seem to be important prey items for small leaf-litter lizards in Atlantic Forest areas. On the other hand, dietary analyses of Gymnodactylus amarali (= G. geckoides amarali) from the Cerrado (COLLI et al., 2003) and G. geckoides from the Caatinga (VITT, 1995) indicated that termites are the most important food item in the diet of these openhabitat species, thus differing from the forest-dwelling congeneric G. darwinii.

Regarding endoparasites, there was no previously available information for Gymnodactylus darwini. In our study, we recorded the occurrence of larvae of Physaloptera (Nematoda: Physalopteridae), for which $G$. darwinii represents a new host. The exotic gekkotan species Hemidactylus mabouia is known to harbor several species of helminths along its extensive geographic distribution in Brazil (ÁVILA; SILVA, 2010). As H. mabouia occurs sympatrically with $G$. darwinii in forest fragments in the study area, it would be interesting to survey the local helminth fauna of that species, to verify whether it also presents a low rate of parasitism at the REGUA.

We conclude that the studied population of $G$. darwinii has a diet exclusively composed of arthropods, with orthopterans, blattarians, and isopods being the most important preys, and that nematodes of the genus Physaloptera occasionally infect the lizards, but apparently with low prevalence. Also, since the individuals found in the lizards were larvae, it is possible that this nematode species may not be able to mature in this particular host. This would indicate that $G$. darwinii represents an intermediate host (ANDERSON, 2000) for this parasite, as it has been suggested for the exotic gecko Hemidactylus mabouia (ANJOS et al., 2005).

\section{Acknowledgements}

This study was supported by research grants from the Conselho Nacional de Desenvolvimento Científico e Tecnológico (CNPq) (processes 304791/2010-5 and 470265/2010-8) and from Fundação de Amparo à Pesquisa do Estado do Rio de Janeiro (FAPERJ) through 
the program "Cientistas do Nosso Estado" (Process E-26/102.404.2009) to C. F. D. Rocha. We thank Nicholas J. Locke of Reserva Ecologica de Guapiaçu (REGUA) for making many facilities available during our fieldwork in that area. M. A. Gomes received $\mathrm{PhD}$ grants from Conservação Internacional do Brasil and FAPERJ. T. Maia-Carneiro received MSc grant from Coordenação de aperfeiçoamento de Pessoal de Nível Superior (CAPES).

\section{References}

ALMEIDA-GOMES, M.; VRCIBRADIC, D.; SIQUEIRA, C. C.; KIEFER, M. C.; KLAION, T.; ALMEIDA-SANTOS, P.; NASCIMENTO, D.; ARIANI, C. V.; BORGES-JUNIOR, V. N. T.; FREITAS-FILHO, R. F.; VAN SLUYS, M.; ROCHA, C. F. D. Herpetofauna of an Atlantic Rainforest area (Morro São João) in Rio de Janeiro State, Brazil. Anais da Academia Brasileira de Ciências, São Paulo, v. 80, n. 2, p. 291-300, 2008.

ANDERSON, R. C. Nematode parasites of vertebrates. Their development and transmission. Wallingford: CAB International, 2000. $650 \mathrm{p}$.

ANJOS, L. A.; ROCHA, C. F. D.; VRCIBRADIC, D.; VICENTE, J. J. Helminths of the exotic lizard Hemidactylus mabouia from a rock outcrop area in southeastern Brazil. Journal of Helminthology, London, v. 79, n. 4, p. 307-313, 2005.

ÁVILA, R. W.; SILVA, R. J. Checklist of helminths from lizards and amphisbaenians (Reptilia, Squamata) of South America. Journal of Venomous Animals and Toxins including Tropical Diseases, Botucatu, v. 16, n. 4, p. 543-572, 2010.

CASSIMIRO, J.; RODRIGUES, M. T. Gymnodactylus darwinii (Darwin's Atlantic Rainforest Naked-toed Gecko). Communal oviposition. Herpetological Review, St Louis, v. 41, n. 3, p. 355 , 2010.

COLLI, G. R.; MESQUITA, D. O.; RODRIGUES, P. V. V.; KYTAYAMA, K. Ecology of the gecko Gymnodactylus geckoides amarali in a Neotropical Savanna. Journal of Herpetology, Salt Lake City, v. 37, n. 4, p. 694-706, 2003.

CORN, P. S. Straight-line drift fences and pitfall traps. In: HEYER, W. R.; DONNELLEY, M. A.; MCDIARMID, R. W.; HAYEK, L. C.; FOSTER, M. S. (Ed.). Measuring and monitoring biological diversity: standard methods for amphibians. Washington: Smithsonian Institution Press, 1994. p. 109-117.
DIAS, E. J. R.; ROCHA, C. F. D. Os répteis nas restingas do Estado da Bahia: Pesquisa e ações para sua conservação. Rio de Janeiro: Instituto Biomas, 2005. 36 p.

DUNHAM, A. E. Realized niche overlap, resource abundance, and intensity of interspecific competition. pp. 261-280. In: HUEY, R.B.; PIANKA, E. R.; SHOENER, T.W. (Ed.). Lizard ecology: Studies of a model organism. Cambridge, Massachussetts and London: Harvard University Press, 1983. 512 p.

FREIRE, E. M. X. Diferenciação geográfica em Gymnodactylus darwinii (Gray, 1845) (Sauria, Gekkonidae). Papéis Avulsos de Zoologia, São Paulo, v. 40, p. 311-322, 1998.

GOLDBERG, S. R.; BURSEY, C. R.; VITT, L. J. Gymnodactylus geckoides (Naked-toed Gecko). Endoparasites. Herpetological Review, v. 41, n. 2, p.223, 2010.

HATANO, F. H.; VRCIBRADIC, D.; GALDINO, C. A. B.; CUNHA-BARROS, M., ROCHA, C. F. D.; VAN SLUYS, M. Thermal ecology and activity patterns of the lizard community of the restinga of Jurubatiba, Macaé, RJ. Revista Brasileira de Biologia, São Carlos, v. 61, n. 2, p. 287-294, 2001.

MAIA, T.; ALMEIDA-GOMES, M.; SIQUEIRA, C. C.; VRCIBRADIC, D.; KIEFER, M. C.; ROCHA, C. F. D. Diet of the lizard Ecpleopus gaudichaudii (Gymnophthalmidae) in the Atlantic Rainforest, state of Rio de Janeiro, Brazil. Zoologia, Curitiba, v. 28, n. 5 , p. 587-592, 2011

PELLEGRINO, K. C. M.; RODRIGUES, M. T.; WAITE, A. N.; MORANDO, M.; YASSUDA, Y. Y.; SITES, J. W. Phylogeography and species limits in the Gymnodactylus darwinii complex (Gekkonidae, Squamata): Genetic structure coincides with river system in the Brazilian Atlantic Forest. Biological Journal of the Linnean Society, London, v. 85, p. 13-26, 2005.

TEIXEIRA, R. L. Aspectos ecológicos de Gymnodactylus darwinii (Sauria: Gekkonidae) em Pontal do Ipiranga, Linhares, Espírito Santo, sudeste do Brasil. Boletim do Museu de Biologia Mello Leitão, Santa Teresa, v. 14, p. 21-31, 2002.

TEIXEIRA, R. L.; FONSECA, F. R. Tópicos ecológicos de Leposoma scincoides (Sauria, Gymnophthalmidae) da região de Mata Atlântica de Santa Teresa, Espírito Santo, sudeste do Brasil. Boletim do Museu de Biologia Mello Leitão, Santa Teresa, v. 15, p. 17-28, 2003.

UETZ, P; HALLERMANN, J. The JCVI/TIGR Reptile Database. 2011. Accessible at <http://www.reptile-database.org>. Accessed on: 30 may 2011.

VITT, L. J. The ecology of tropical lizards in the Caatinga of northeast Brazil. Occasional Papers of the Oklahoma Museum of Natural History, Norman, v. 1, p. 1-29, 1995. 